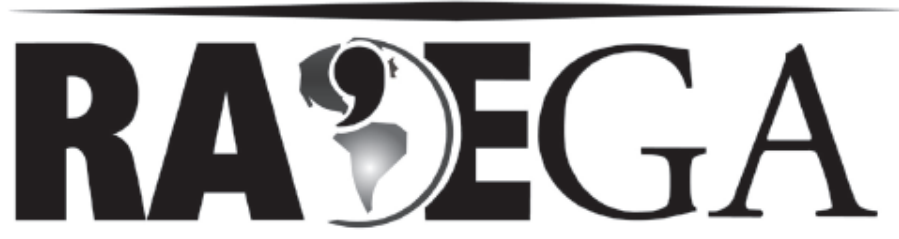

O ESPAÇO GEOGRÁFICO EM ANÁLISE

\title{
RESIDÊNCIAS SECUNDÁRIAS E O ESPAÇO RURAL: MANIFESTAÇÕES E DINÂMICAS NA SOCIEDADE CONTEMPORÂNEA
}

\author{
SECONDARY HOMES AND THE RURAL SPACE: \\ EVENTS AND DYNAMICS IN THE CONTEMPORARY \\ SOCIETY
}

\author{
Elvis Albert Robe WANDSCHEER ${ }^{1}$ \\ Michele LINDNER ${ }^{2}$ \\ Marcelino de SOUZA ${ }^{3}$
}

\section{RESUMO}

Muito embora o fenômeno de residências secundárias não se constitua num evento recente, o mesmo tem se destacado em virtude dos novos contornos que denota aos espaços em que se manifesta, sobretudo quando situado em espaços rurais. Diante desta perspectiva, o presente trabalho visa estudar as mobilidades espaciais em residências secundárias no meio rural, nos seus fluxos de finais de semana e de veraneio, de forma a analisar as ações, interações e dinâmicas estabelecidas com os espaços enfocados. A pesquisa foi realizada nos municípios de Itaara e Restinga Seca, Rio Grande do Sul -

\footnotetext{
${ }^{1}$ Geógrafo e Economista pela Universidade Federal de Santa Maria (UFSM), Mestre em Desenvolvimento Rural (PGDR) e Doutorando em Geografia pela Universidade Federal do Rio Grande do Sul (UFRGS). e-mail: elvishz@yahoo.com.br

${ }^{2}$ Geógrafa, Especialista em Geociências e Mestre em Extensão Rural pela Universidade Federal de Santa Maria (UFSM), Doutoranda em Geografia pela Universidade Estadual Paulista "Júlio de Mesquita Filho" (UNESP), campus Rio Claro. e-mail: michelindner@gmail.com

3 Agrônomo pela Universidade Estadual de Londrina, Mestre em Extensão Rural pela Universidade Federal de Santa Maria (UFSM), Doutor em Engenharia Agrícola pela Universidade Estadual de Campinas (UNICAMP). Professor do Programa de Pós-graduação em Desenvolvimento Rural (PGDR) da Universidade Federal do Rio Grande do Sul (UFRGS).e-mail: marcelino.souza@uol.com.br
} 
Brasil. Metodologicamente, a pesquisa contou com: revisão bibliográfica; coleta de dados quali-quantitativos, onde utilizaram-se questionários aplicados a 86 visitantes e 25 entrevistas com os gestores públicos municipais, iniciativa privada e comunidade local. Os resultados demonstram que o fenômeno de residências secundárias afeta em várias dimensões os espaços nos quais manifesta-se, bem como apresenta distinções na relevância das periodicidades dos fluxos, uma vez que divergem em intensidade e heterogeneidade na forma em que atuam no espaço e relacionam-se com o seu entorno.

Palavras-chave: Residências Secundárias; Mobilidades Espaciais; Espaços Rurais

\title{
ABSTRACT
}

Despite the fact that the secondary home phenomenon is not a recent event, this has detached itself in face of the new outlines that it denotes to the space where it occurs, mainly when it is situated in rural spaces. Given this perspective, the present work aims to study the spatial mobilities related to secondary homes localized in the rural medium, in their weekend and summer resort fluxes, in a way of analyzing the actions, interactions and dynamics established in the focused spaces. The research was conducted in Itaara and Restinga Seca cities, localized in Rio Grande do Sul state, Brazil. Metodologically, it counted with bibliographic revision and quali-quantitative data collection, where we utilized question forms applied to 86 visitors and 25 interviews with municipal public administrators, private initiative and local community. The results showed that the secondary homes phenomenon affects the space where it occurs in various dimensions. They also showed that there are some differences concerning the importance attained by the periodicity of the fluxes, since they diverge in the intensity and the way in which they act in the space and relate with its surroundings.

Key-Words: Secondary homes; Spatial motilities; Rural space

\section{INTRODUÇÃO}

\begin{abstract}
Em um mundo visto como uma totalidade em movimento, o espaço pode ser visto como uma forma-conteúdo, forma que não pode ser separada do conteúdo e vice-versa, confundindo objetos e ações, mediante uma intencionalidade, em um permanente movimento de dissolução e recriação do sentido, produzindo e reproduzindo 0 espaço como um híbrido (SANTOS, 2004, p. 24-25).
\end{abstract}

As mudanças pelas quais a sociedade contemporânea passou, no século $X X$, sobretudo em sua reestruturação, no último quarto do século $X I X$, forjaram um novo significado ao termo tempo e, logo, fomentaram reflexões 
mais amplas sobre o período em que as pessoas podem e têm buscado, cada vez mais, destinar a outros fins, que não dizem respeito ao trabalho e à sua qualificação profissional. Também, a demanda gerada pelo maior fluxo de informações em função das tecnologias da informação e comunicação modificaram os próprios tempos e ambientes de trabalho.

Não obstante a essa realidade, outro fato igualmente relevante e, ao mesmo tempo complementar, refere-se à urbanização ocorrida nas distintas sociedades, inclusive, aquelas situadas na "periferia" do sistema capitalista, dentre as quais se pode salientar a brasileira. Tal quadro repercutiu no cotidiano urbano dessas sociedades, influenciando modos de vida, de produção, de consumo e, mesmo, das próprias relações humanas.

Em resposta a essa realidade que norteia o tempo e seu uso, bem como as problemáticas intrínsecas às novas demandas do século $\mathrm{XXI}$, as pessoas cada vez mais têm efetuado investimento(s) pessoal(is) e/ou familiar(es) no intuito de buscar outros espaços, outras configurações espaciais e paisagens que repercutam em outras visões, que fujam aos padrões habituais. Essas visões, não raro, caracterizam-se por paisagens rurais que se pautam na diversidade dos potenciais naturais, históricos, patrimoniais e culturais, assim evidenciada por Graziano da Silva (1999, p. 189):

[...] o campo brasileiro não pode mais ser caracterizado como um espaço eminentemente agropecuário; ao contrário, ganham importância outras dimensões, como as de moradia, de transformação industrial e inclusive as não-produtivas no sentido estrito do termo, como o lazer e a preservação ambiental.

Cabe salientar que esse fenômeno discutido por Graziano da Silva não se constata como inteiramente novo na sociedade rural, dado que muitas dessas dimensões já possuem registros que datam de experiências há mais de século existentes no campo. Contudo, há algum tempo, os fenômenos de novas ruralidades ganham expressão cada vez mais ampla e pujante no espaço rural, conferindo ao mesmo um novo valor, uma ressignificação.

Cabe salientar, ainda, a ressignificação da ruralidade enquanto enfoque contrário à visão dicotômica rural-urbana. Trata-se de abordar o espaço rural levando-se em conta as novas características nele imbricadas, mantendo-se 
muitos dos atores e agentes anteriormente conhecidos e tradicionalmente expressos na paisagem rural. Entretanto, agora contemplando inserções de novos agentes (como os habitantes urbanos em suas demandas pelo rural e seus produtos) e, tão logo, expressando as novas visões norteadoras do meio rural, visões essas que abarcam novos valores oriundos das transformações e novas necessidades da sociedade contemporânea.

A nova ruralidade ${ }^{4}$ constitui-se numa abordagem diferenciada, sendo muito mais a percepção de que, atualmente, velhos espaços passaram a conferir novos valores e a compreender distintas funções abarcando elementos que orientam determinados enfoques referentes à ruralidade e, ao mesmo tempo, consolidam ideias ou significações norteadas pelo enfoque ao qual o observador, principalmente o habitante citadino, volta seus olhares. Tão logo, vislumbram-se, no espaço rural, demandas de atividades, ocupação e organização do espaço não restritas somente ao âmbito da produção agrícola. Com isso, surgem outras formas de refletir e analisar o espaço rural de forma que o mesmo incorpore os fenômenos que o cercam. Essas análises abarcam a multifuncionalidade ${ }^{5}$ do rural e a pluriatividade ${ }^{6}$ no rural contemporâneo, dentre as quais a mobilidade espacial exerce um papel de destaque frente a essas dinâmicas.

Nesse contexto, a existência e o crescimento de atividades rurais nãoagrícolas, mesmo diante da gama de controvérsias que norteiam sua discussão, cada vez mais se expandem e ganham novos enfoques na literatura rural, sobretudo a brasileira. Em vista dessa realidade, o rural contemporâneo demonstra englobar uma série de atividades, patrimônios e práticas sócioespaciais multifacetadas, que interagem na organização do mesmo, interligando as esferas e dinâmicas locais, dentre as quais, as residências secundárias constituem-se numa das demandas existentes nesses espaços.

\footnotetext{
4 "[...] a ruralidade seria muito mais ampla e complexa do que a atividade econômica agrícola que é praticada. A segunda perspectiva de análise da ruralidade centra-se mais acentuadamente nos aspectos sociológicos e etnográficos relacionados às formas de construção e redefinição das identidade sociais, da cultura, da sociabilidade e dos modos de vida." (Schneider; Blume, 2004, p. 111).

${ }^{5}$ De acordo com Almeida (2003, p. 457): "[...] a abordagem multifuncional da agricultura abre a atividade agropecuária a possibilidade de repensar radicalmente a forma de conceber o desenvolvimento rural que passa de uma visão setorial para uma visão integrada [...]".

Conforme Schneider (2003, p. 77-79) a expressão consiste numa: "[...] referência analítica à disseminação do fenômeno da diversificação das atividades e das fontes de renda das unidades familiares agrícolas [...]".
} 
Os termos utilizados para se referirem ao mesmo fenômeno de residências secundárias se apresentam de forma diferenciada na literatura nacional e internacional e "observamos que, apesar da definição técnica do IBGE, a residência secundária ou segunda residência é um conceito amplo e complexo que, pela profusão de termos restritivos [...] ainda carece da falta de um consenso terminológico (ASSIS, 2003, p. 5)". Comumente, salienta-se que o uso desse tipo de residência envolve uma variedade de aspectos, tais como: o deslocamento de pessoas, ocupação de domicílios de forma não permanente, geração de oportunidades e ampliação da infraestrutura, dentre outros, vindo a, inclusive, ocasionar mudanças substanciais quando de sua instalação. Porém, indiferentemente da terminologia utilizada, destaca-se que essa é uma modalidade de alojamento cada vez mais demandada, perfazendo uma modalidade espacial peculiar que atribui e relaciona-se estreitamente com o espaço, produzindo relações que incidem em distintas esferas no âmbito local.

Relativamente ao paradigma da residência secundária, e para além do que já foi dito, ainda há muito a investigar. No caso de se concluir que este fenômeno é uma benção, há que traçar estratégias para o seu desenvolvimento. Caso contrário, é de ensaiar algumas medidas inibidoras [...], mas também ao nível da concepção dos espaços residenciais do quotidiano, tentando oferecer condições de vida que conduzam à realização pessoal nesses locais, oferecendo cenários que tradicionalmente se têm procurado fora da cidade [...] (SAMPAIO, 2000, p. 140).

Dessa forma, no intuito de mais bem compreender as mobilidades espaciais no espaço rural por meio das residências secundárias nos fluxos de finais de semana e de veraneio, formularam-se os seguintes questionamentos: como se expressam e quais as características das interações e integrações existentes entre as mobilidades oriundas da existência de residências secundárias no espaço rural? Para tanto, tomou-se como base as manifestações do fenômeno nos municípios de Itaara e Restinga Seca, tendo o município de Santa Maria/RS como seu principal polo emissor. Os municípios de Itaara e Restinga Seca, no estado do Rio Grande do Sul - Brasil, conforme pode ser visualizado na figura 1. 


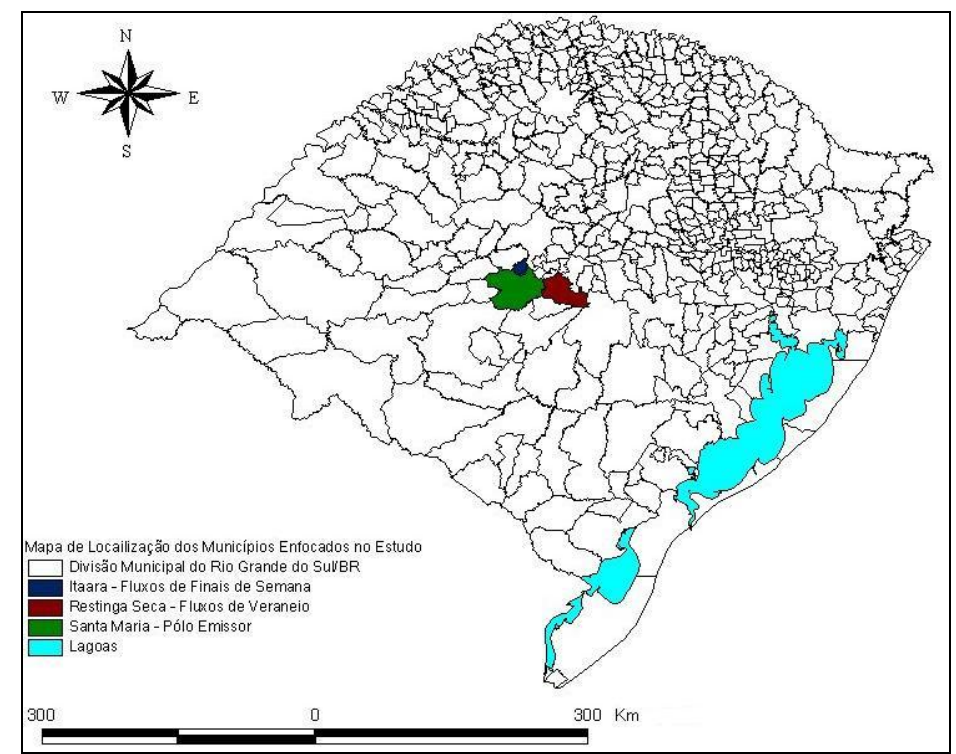

Figura 1. Mapa com a localização dos municípios estudados Fonte: IBGE (2009).

Assim, como apresentado na figura 1, Itaara e Restinga Seca situamse na circunvizinhança do município de maior expressão de centro urbano da porção central do Estado - Santa Maria - ainda que não façam parte da mesma microrregião geográfica, pois Restinga Seca pertence à Microrregião Geográfica de Restinga Seca, ao passo que Itaara pertence à Microrregião Geográfica de Santa Maria. Essa localização física contribui para a manifestação do fenômeno de residências secundárias (ainda que não de forma homogênea, em ambos, nas dinâmicas dos fluxos de mobilidades espaciais).

Porém, outros aspectos caracterizam fortemente os municípios de Itaara e Restinga Seca, os quais consistem na existência de um considerável contingente de pequenos agricultores, caracterizados como agricultores familiares. Conforme Rodrigues (2005, p. 75) apud EMATER, em Itaara, "[...] $70 \%$ das propriedades possuem até 20 ha, $15 \%$ de 20-100 ha, e os restantes, $15 \%$, excedem os 100 ha”. Quanto a Restinga Seca, segundo Schneider 
(2007), "há uma polarização entre propriedades de tamanho muito pequeno (com menos de 5 hectares), em torno de 24\%, e as propriedades de mais de 50 hectares, em torno de 40\%", ou seja, cerca de $60 \%$ das propriedades constituem-se em pequenas ou médias.

Ainda quanto aos municípios em questão, pode-se afirmar que os mesmos apresentam uma população relativamente pequena, de 4.633 habitantes em Itaara e 15.595 em Restinga Seca (IBGE, 2007). Sendo que, em relação à população, Restinga Seca abriga cerca de $50 \%$ de sua população fora do perímetro urbano, ao passo que Itaara apresenta cerca de $30 \%$ da população total localizada em área rural, conforme dados do IBGE (2007).

Nesse sentido, o presente trabalho visa estudar as mobilidades espaciais originadas em função das residências secundárias existentes no meio rural através de seus fluxos de finais de semana e de veraneio, de forma a analisar as ações, interações e dinâmicas estabelecidas com os espaços enfocados.

\section{METODOLOGIA DA PESQUISA}

Com o presente estudo, buscou-se descrever, entre outros aspectos, as mobilidades espaciais de fluxos de finais de semana e de veraneio em espaços rurais nos municípios de Itaara e Restinga Seca derivados da existência das residências secundárias. Para tanto, a pesquisa contou, primeiramente, com uma etapa de levantamento de informações e pesquisa bibliográfica para, então, coletar dados junto às pessoas nos municípios por meio de entrevistas semiestruturadas e questionários. Cabe salientar que a pesquisa foi realizada nos meses de Fevereiro e Março de 2008.

A escolha dos municípios de Itaara e Restinga Seca, para a realização do presente estudo, não foi aleatória, mas guiada por um propósito de abarcar a diversidade de dois fluxos distintos (de finais de semana e de veraneio, respectivamente) que têm suas visitas orientadas por um polo emissor em particular, o município de Santa Maria, partilhando, dessa forma, as características de suas emissões. A metodologia utilizada na coleta de dados 
baseia-se na combinação dos métodos quali-quantitativos, por meio de observação não-participativa, entrevistas semiestruturadas e questionários. A amostragem foi a não-probabilística intencional, na qual: "[...] seleciona um grupo de elementos considerados típicos, em função das variáveis estudadas [...] O critério da escolha, neste tipo de amostra, é a razão e não o aleatório, mas a razão é fundada nos critérios pré-estabelecidos (ALMEIDA, 1989, p. 87)".

$\mathrm{Na}$ pesquisa em questão, utilizou-se a amostra não-probabilística acidental na aplicação de entrevistas à iniciativa privada, junto à comunidade, aos estabelecimentos comerciais situados no entorno das áreas de residências secundárias, bem como à comunidade, procurando abranger o maior número possível de indivíduos habitantes nos dois municípios pesquisados. Porém, em relação às entrevistas efetuadas com o poder público, utilizou-se a amostra intencional, na qual se efetuou uma seleção, um direcionamento. Tal escolha dos entrevistados foi realizada em função das orientações recebidas do poder público local, que designou dois indivíduos da composição do seu quadro. Indivíduos estes considerados melhores indicados a responder questões sobre a temática e/ou áreas na(s) qual(is) a(s) residências secundárias encontram-se situadas.

O instrumento qualitativo da entrevista semiestruturada foi formulado com o intuito de abranger elementos que se fizeram necessários diante da situação, ou seja: "[...] pressupõe que não se conhece bem a população que será entrevistada, ele precisa de uma estratégia diferente, mais flexível [...] visa obter do entrevistado o que ele considera os aspectos mais relevantes de determinado problema [...] (RICHARDSON, 1999, p. 208)". O universo da pesquisa referente aos entrevistados do poder público contou com quatro representantes da gestão pública municipal, dois do município de Itaara e dois do município de Restinga Seca; sendo eles: o Secretário da Agricultura, Indústria e Comércio e um funcionário da Secretaria de Turismo no primeiro município; já no segundo município, foi representado pelo Prefeito Municipal e o Secretário Executivo da Câmara de Vereadores. 
Em relação à iniciativa privada, as entrevistas contaram com a participação de seis pessoas em cada um dos municípios pesquisados. Em Itaara, foram coletados dados com proprietários de dois supermercados, de uma fruteira, de uma associação de agricultores que comercializava produtos agrícolas, de um proprietário de uma drogaria e com proprietários de uma livraria e bazar. Já em Restinga Seca, as entrevistas foram aplicadas junto a proprietários e funcionários de um bazar, de um mini-mercado, de uma sorveteria, de um restaurante e de duas lancherias.

A sequência das entrevistas foi feita com a população local, ou seja, a comunidade. Esta etapa foi realizada com a participação de sete indivíduos no município de Itaara e quatro no município de Restinga Seca. Em Restinga Seca, cabe salientar que, dada a concentração das residências secundárias em uma única área e a existência de poucos moradores autóctones nela e em seu entorno, apresentando distribuição local dispersa e, ainda, somada à baixa interação social (como por exemplo, nas atividades comerciais), esses aspectos dificultaram a ampliação do universo da população pesquisada.

Os questionários, por sua vez, constituíram-se como ferramenta quantitativa da pesquisa, tendo na padronização possibilitada pelos mesmos, juntamente com a maior facilidade oferecida pela cobertura da área a ser pesquisada (fator que possibilitou a coleta de um número maior de dados no período de tempo estabelecido), vantagens consideráveis frente à limitação imposta pela temporada de veraneio. Esse fator valoriza, sobremaneira, a utilização dos questionários para com os visitantes (tanto proprietários quanto locatários), uma vez que não havia garantias de que os mesmos seriam encontrados nas suas residências secundárias, pois conforme o próprio termo remete, elas se constituem em habitações nas quais não existem moradores permanentes e poucas eram as referências acerca das mesmas, mesmo nas bibliografias específicas que tratavam desses municípios.

Tal realidade apresentou reflexos na coleta de dados, uma vez que acarretou diferenças numéricas de questionários. Enquanto a área localizada no espaço rural de Tunas, no município de Restinga Seca, possibilitou a coleta de 53 questionários - totalizando informações de 214 indivíduos -, no município 
de Itaara, onde as residências encontravam-se mais dispersas, foi possível a aplicação de 33 questionários - totalizando informações de 139 indivíduos. No total, foram aplicados 86 questionários, totalizando 353 indivíduos.

O delineamento da análise da pesquisa caracteriza-se como sendo analítico-descritivo, tendo as estratégias de pesquisa atuações complementares ao longo do mesmo. O estudo descritivo contemplou: "[...] conhecer e descrever as diversas relações que ocorrem na vida política, social, econômica que ocorrem tanto com um indivíduo, tomado separadamente ou com grupos ou comunidades mais complexas" (CERVO \& BERVIAN, 2002, p. 66). O estudo analítico, por sua vez, procurou estabelecer e analisar relações entre as variáveis, uma vez que esses estudos são baseados sobre fatos e têm como ponto de partida as relações, para explicar determinados fenômenos em particular (ALMEIDA, 1989); este é o caso das residências secundárias e mobilidades espaciais originadas em virtude destas no espaço rural.

A primeira etapa da análise consistiu na tabulação dos dados e informações coletadas a partir da transcrição das entrevistas, assim, fazendose uso da análise de conteúdo. Os questionários, por sua vez, cumpriram a etapa quantitativa do presente estudo, sendo tabulados separadamente por município (Itaara e Restinga Seca). Os mesmos apresentam os quesitos de perguntas fechadas. A tabulação desses dados coletados levou em consideração quatro âmbitos de questões específicas que se referiam aos visitantes e familiares, residências secundárias - nas quais os mesmos se encontravam -, infraestrutura local e período abrangido por essa permanência, ao encontro do fato de que "Qualquer que seja a área, sempre existem questões que remetem a fatos e questões que remetem a dados (COSTA, 2003, p. 10)". Por fim, utilizou-se o software SPSS 12 no intuito de tabular e interpretar os dados coletados nos questionários, cujos resultados apresentamse no presente trabalho. Para a análise das entrevistas, utilizou-se a análise de conteúdo, sendo estabelecidas dez categorias, nas quais distinguiram-se temáticas com fim de possibilitar uma sistematização e codificação dos dados. 


\section{REVISÃO BIBLIOGRÁFICA}

O "novo rural" ao qual muitos autores reportam-se, que tem em José Graziano da Silva o seu pioneiro, é composto basicamente de três grandes grupos conforme apontam Del Grossi e Graziano da Silva (2002, p. 5):

1. Uma agropecuária moderna, baseada em commodities e intimamente ligada às agroindústrias; 2 . Um conjunto de atividades não-agrícolas, ligadas à moradia, ao lazer e a várias atividades industriais e de prestação de serviços; 3 . Um conjunto de "novas" atividades agropecuárias, localizadas em nichos especiais de mercados.

Dentre esses grupos e não desconsiderando os demais, o dito "conjunto de atividades não-agrícolas" já não é capaz de expressar o cidadão urbano ou rural, tampouco a sua residência (GRAZIANO DA SILVA, 1999, p. 63). O autor afirma, inclusive, ser essa uma das tendências marcantes dos anos 90 como um todo no mundo e, em persistindo tal tendência, ao que parece ser o caso neste início do século XXI, desdobram-se fluxos (populacionais e econômicos) tais quais os continuuns rural-urbanos, compondo os chamados povoamentos modernos.

\footnotetext{
Provavelmente uma parte significativa das ocupações não-agrícolas desse rural-invadido-pelo-urbano deve-se a pessoas que buscam aí um espaço de moradia por razões econômicas ou de melhor qualidade de vida, mas mantêm suas ocupações em setores tipicamente urbanos. Esse é um filão que merece ser melhor explorado [...] (GRAZIANO DA SILVA, 1999, p. 71).
}

Veiga, ao abordar a nova dinâmica da economia rural, afirma: "Foi-se o tempo em que a virtude da cidade era 'arrancar a população do embrutecimento da vida no campo' (VEIGA, 2003 p. 99)". Configuram-se, assim, de um lado, manutenções de estruturas e relações antigas que vêm emergir de outro e têm de conviverem e se relacionarem (ao menos no limite da tolerância) agora com atores "deslocados" de seus antigos espaços, assumindo novos papéis e tecendo novas realidades. A essas relações, evidenciam-se novas possibilidades de reflexão das relações vigentes no espaço de forma a convergir com o final da pertinência biunívoca entre rural 
agrícola e urbano não-agrícola; assim, como a importância do debate sobre a existência das residências secundárias. Por residência secundária compreende-se um conjunto de abordagens que, não raro, costumam contemplar o mesmo significado em termos de extensão de imóveis à qual se reportam.

\begin{abstract}
Casas de temporada, de praia, de campo, chalé, cabana, rancho, sítio ou chácara de lazer são alguns dos termos comumentemente aplicados às propriedades [...] utilizadas temporariamente, nos períodos de tempo livre, por pessoas que têm sua residência permanente em outro lugar. A profusão de vocábulos populares para denominar esse meio de hospedagem extra-hoteleiro resulta das várias características e finalidade de uso de tais imóveis [...] No Brasil, essa questão se resolveu a partir dos censos demográficos realizados, respectivamente, em 1980 e 1991, quando surge uma categoria separada das demais constituída pelos domicílios de uso ocasional [...] (TULIK, 2001, p. IX).
\end{abstract}

Dessa forma, reconhecidamente, essa terminologia é contabilizada nos dados do IBGE por meio de suas sinopses preliminares ${ }^{7}$, sendo tratada como domicílio de uso ocasional. Inicialmente, de 1970 até 1980, o IBGE tratou o fenômeno como: "[...] domicílios que serviam ocasionalmente de moradia (casa de praia, ou campo, normalmente usadas para descanso de fim-de-semana ou férias) e cujos moradores não estavam presentes na data do Censo (sinopse preliminar do IBGE apud TULIK, 2001)"; passando mais tarde, já na década de 90 (1991 mais precisamente) a distinguir-se aqueles de uso ocasional dos imóveis fechados e vagos.

Dessa forma, por residência secundária pode-se compreender um imóvel de uso ocasional que serve ocasionalmente de moradia (casa ou apartamento) normalmente usado para descanso de fim-de-semana ou férias (IBGE apud SENA; QUEIROZ, 2006). Ainda, cabe salientar alguns aspectos relevantes a esse fenômeno que norteia a existência e a diferenciação de local para local, a que ainda não fora feita referência alguma.

[...] Sendo um fenômeno recente que se vincula ao turismo de fim de semana e das férias anuais. A residência secundária tem sua

\footnotetext{
${ }^{7}$ Conforme Tulik (2001, p. X): “[...] Justifica-se a utilização da Sinopse Preliminar por ser o único recurso possível, já que o Instituto Brasileiro de Geografia e Estatística (IBGE) não divulga, em sua edição definitiva, dados referentes aos domicílios vagos, fechados e de uso ocasional, este último aqui entendido como residência secundária".
} 
localização definida pela relação tempo-custo-distâncias. Esse tripé (tempo-custo-distância) pode, em alguns casos, definir a localização das segundas residências na zona urbana ou rural e influenciar na concentração dessas construções em determinadas áreas. A disponibilidade de renda e de tempo livre influencia na escolha da localização da segunda residência, pois, quanto mais distante da residência permanente, maior é o tempo e o custo de acesso a este domicílio de uso ocasional. A propriedade de uma segunda residência em áreas muito distantes da residência principal inviabiliza a sua freqüência assídua nos finais de semana, levando o proprietário a usá-la, principalmente, nas temporadas de férias nas quais pode se dispor de um tempo maior de estadia (SENA \& QUEIROZ, 2006, p. 99).

Uma vez estabelecida a denominação e sua contextualização, reportarse à sua magnitude concilia observações empíricas e cientificamente observadas, na qual se desenrolam aspectos positivos e negativos, suplantando a mera consideração de um, sem algum grau de presença do outro. Tanto se apoiando nos exemplos e referências estrangeiras quanto em se analisando os casos nacionais, observam-se relevância e curiosidades do fenômeno em diversos níveis conforme pode-se observar na abordagem de Hall \& Müller (2004, p. 3):

[...] Em muitos lugares do mundo, residências secundárias são o destino de uma proporção substancial de viajantes domésticos e internacionais, enquanto o número de noites dormidas em residências secundárias muitas vezes compete ou até mesmo excede aquelas disponíveis no setor de acomodação formal. Para muitos locais, particularmente em áreas mais periféricas, residências secundárias são um dos contribuintes principais da economia regional, mas eles também podem representar um recurso significativo de herança, dado - uso de arquiteturas vernaculares e o uso progressivo de construções que, em caso contrário, poderiam ter desaparecido [...] (Tradução nossa).

Trazendo este debate para o âmbito do rural, considerar-se-á:

[...] a noção da grande diversidade do meio rural, que encerra realidades bem diferentes, a exigirem soluções específicas diferentes e, sobretudo adequadas [...] que tenham em atenção a heterogeneidade do meio, a traduzir-se também no facto de a diversidade já existente entre áreas rurais ir muito além da densidade populacional e do uso do solo para fins agrícolas [...] (LOPES, 2003, p. 291).

Enquanto fenômeno do meio rural cabe ressaltar que estatística e publicamente pouco ou nada reconhecida pela sociedade, as residências 
secundárias se manifestam em muitos países, assim como no Brasil há algum tempo, deixando marcas e afirmando presença por meio de impactos de distintas ordens, como abordar-se-á posteriormente em suas repercussões espaciais.

Destaca-se, por fim, que essa manifestação não se constitui unicamente como fenômeno característico de países desenvolvidos como Portugal, Espanha e França (países que possuem uma bibliografia mais ampla e específica acerca do tema), nem tampouco que o mesmo tenha outro nível de significação e relevância nesses ou noutros países desenvolvidos. O que perdura são as diferentes manifestações dadas às diferentes estruturas sócioespaciais vigentes nos distintos países.

\section{AS PAISAGENS DE ITAARA E RESTINGA SECA: ATRATIVOS E PECULIARIDADES DESSES ESPAÇOS DE RESIDÊNCIAS SECUNDÁRIAS}

A paisagem de Itaara apresenta uma série de belezas naturais assentadas, sobretudo, na diversidade de sua flora, áreas de campos ondulados com espécies de araucária, bem como atividades agrícolas contrastando com outras partes do município, com vales (canyons) e áreas consideradas impróprias para a atividade agropecuária. Somam-se a essa diversidade o seu destacado potencial fluvial, composto por lagos, rios e cachoeiras situados em seus limites físicos, aspectos que transmitem um ar predominantemente rural.

Em Itaara, as temperaturas apresentam-se mais baixas que as identificadas nos municípios vizinhos por situar-se no rebordo do planalto basáltico do Rio Grande do $\mathrm{Sul}^{8}$. Tais temperaturas favorecem que, no período do verão, o ambiente apresente um aspecto de "bem-estar" aos visitantes, conforme destacado por eles próprios. Já no inverno, essas temperaturas mais baixas conformam ares "serranos" (mesmo não se tratando de um município situado na Serra Gaúcha), com utilização de lareiras e fomento da gastronomia local, que envolve principalmente produtos ítalo-brasileiros, típicos da região da

\footnotetext{
8 O município de Itaara engloba a transição dos compartimentos geomorfológicos do planalto sul riograndense e a depressão periférica riograndense.
} 
Quarta-Colônia ${ }^{9}$, vizinha ao município. Destaca-se, frente a essa característica, a existência de uma vinícola que fornece produtos não apenas nos estabelecimentos situados no perímetro municipal, mas também, comercializa os mesmos em outras cidades da região.

Em virtude da diversidade da paisagem encontrada, Itaara apresenta várias residências secundárias, dispersas ao longo da sua extensão territorial, concentrando-se maior número dessas em espaços de balneários, os quais totalizam onze, sendo que dez são privativos e concentram as residências secundárias, diferentemente do único de uso público. Na maioria desses balneários autoriza-se a circulação de visitantes, temporariamente, com o objetivo de conhecer o local. Os balneários constituem-se em atrativo para os visitantes mesmo no período anterior à emancipação de Santa Maria (fato que ocorreu no ano de 1995).

O município de Restinga Seca, por sua vez, apresenta uma organização municipal característica dos municípios do interior do estado do Rio Grande do Sul, de economia baseada principalmente no setor agropecuário. Sua estrutura é composta por um núcleo urbano central onde está situada a área comercial do município, havendo, fora desse espaço, apenas pequenos estabelecimentos que, em grande parte, localizam-se nos limites do balneário Praia de Tunas, área na qual se encontram as residências secundárias.

Essa área que comporta o balneário da praia de Tunas está localizada à margem do rio Vacacaí-Grande. O município, que apresenta uma demanda turística centrada quase unicamente no balneário da praia de Tunas, possui, conforme a própria denominação, características próprias das praias, uma vez que há áreas de banho, espaços para exposição ao sol na areia à beira da água (espaços esses formados por depósitos de sedimentos no leito do rio), quiosques e lanchonetes igualmente situados próximos à margem do rio. $\mathrm{O}$ local apresenta, ainda, atrativos referentes à infraestrutura, onde se verifica a presença de vias de acesso em boas condições, abastecimento de água,

\footnotetext{
${ }^{9}$ A região da Quarta Colônia é composta por nove municípios: Agudo, Dona Francisca, Faxinal do Soturno, Ivorá, Nova Palma, Pinhal Grande, Restinga Seca, São João do Polêsine e Silveira Martins, que apresentam um grande percentual de habitantes rurais e a origem dos mesmos é, na sua maior parte, composta de descendentes de imigrantes italianos que chegaram a esta região no final do século XIX.
} 
energia elétrica, telefone, serviço de limpeza pública e espaços de lazer, como: quadras de areia para a prática de futebol e voleibol, além de canchas de bocha cobertas e sombras que abrigam estruturas para descanso e propícias à elaboração do prato típico do Rio Grande do Sul, o churrasco.

A água constitui-se num elemento central da demanda dos fluxos que visitam o local, de forma que quando ocorre um grande volume de chuvas, os espaços de lazer ficam comprometidos e a própria infraestrutura acaba sendo afetada. Igualmente, são frustrantes, para os visitantes, os níveis da água muito baixos (em períodos de estiagem), por comprometerem as áreas de banho.

Muito embora haja um consumo alimentar importante nesta área e a produção agrícola esteja situada no entorno do balneário, uma grande demanda por produtos agrícolas não foi verificada no local, sendo esses alimentos trazidos pelos próprios visitantes ou, então, adquiridos no pequeno mercado existente no local, que dispõe de poucos produtos provindos, em grande parcela, do comércio central do município.

A temperatura consiste em um fator interessante no espaço em questão, uma vez que, de um lado, estimula os fluxos em direção ao balneário, à medida que o público demandante deste espaço é motivado pelas características similares àquelas encontradas em praias, ou seja, constituemse em demandas tipicamente de veraneio. De outro lado, a demanda turística representa um mercado sazonal para os produtos agropecuários, que exigiriam uma adaptação (até o momento inexistente) por parte da produção agrícola local para que fosse consolidada a comercialização entre os agricultores e a demanda dos visitantes que frequentam essa área. A exemplo dessa realidade existem no município de Restinga Seca outros três balneários, sendo dois públicos (balneário Colônia Borges e Jacuí) e um particular (balneário Meia Lua), que vivenciam dinâmicas muito semelhantes, porém, praticamente inexistem residências secundárias nesses espaços, além do fato de as mesmas apresentarem infraestrutura inferior e, logo, apresentam demandas igualmente menores. 
Cabe destacar que mesmo o município tendo sua localização geográfica numa área pertencente à denominada região da Quarta-Colônia (de destacado patrimônio cultural, herança da colonização ítalo-brasileira, visualizada principalmente em suas edificações e na gastronomia local), esse não apresenta nenhum desses potenciais da região (as residências não apresentam traços característicos de arquiteturas italianas tampouco é explorada a gastronomia dessa região, embora haja certo reconhecimento dos potenciais turísticos centrado nesta herança cultural). Além disso, observou-se que, no balneário Praia de Tunas, o consumo dos visitantes não permite ou estabelece relações entre o comércio e os produtores. Os produtos locais tampouco contribuem para a redução dos valores dos produtos de forma que permanece inexplorado o mercado consumidor desses visitantes para os agricultores locais. Também, a iniciativa privada apresenta deficiências para abastecimento da demanda existente no período de veraneio.

\section{O FENÔMENO EM FOCO}

A existência de residências secundárias não se constitui num fenômeno absolutamente recente tanto no município Itaara quanto em Restinga Seca/RS. Dessa forma, interessa identificar especificamente há quanto tempo essas residências existem nestes municípios, consolidando-se como modalidade distinta de habitação. No gráfico 1, são apresentadas as distribuições das residências secundárias de acordo com o tempo de existência nos municípios estudados.

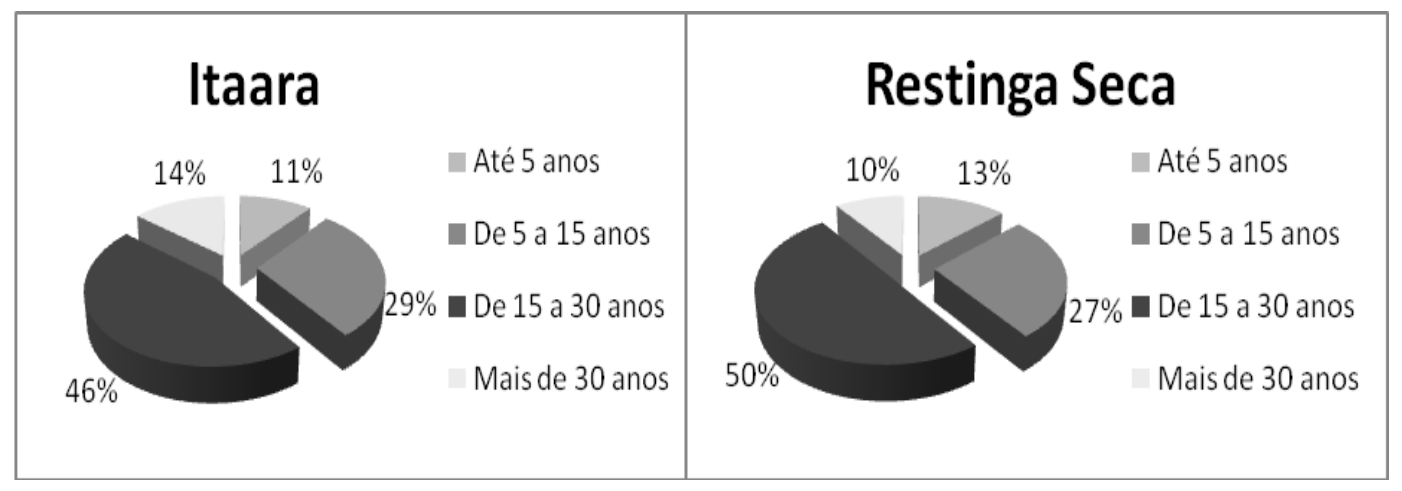

Gráfico 1: Distribuições das Residências Secundárias, de acordo com o tempo de existência. Fonte: Pesquisa de Campo (2008). 
Tanto no município de Itaara quanto no município de Restinga Seca, cerca de $10 \%$ das residências secundárias possuem mais de trinta anos de existência. Porém, a maior incidência refere-se a um período relativamente recente de 15 a 30 anos, em ambos os municípios, totalizando aproximadamente a metade dos percentuais de cada um.

Observa-se, a partir do gráfico 1, que a distribuição das residências secundárias, de acordo com o tempo de existência nos municípios de Itaara e Restinga Seca, é semelhante e, portanto, a característica de tempo de existência não causa disparidade nas análises do fenômeno no que concerne às suas diferentes manifestações nos municípios. Cabe ressaltar, ainda, que a semelhança existente entre as distribuições quanto ao tempo de existência das residências secundárias nos municípios assemelha-se, inclusive, no que concerne ao seu crescimento ao longo dos anos, sendo que, no período dos últimos cinco anos, apresentaram taxas de 11 a 13\% conforme se verificou na pesquisa.

$\mathrm{Na}$ tabela 1, estão apresentadas as distribuições das situações das residências secundárias nos municípios analisados, sendo possível observar, segundo a condição de ocupação: próprios, emprestados ou alugados.

\section{Tabela 1. Distribuição das Residências Secundárias em Itaara e Restinga} Seca, segundo as condições de ocupações

\begin{tabular}{c|c|c|c|c}
\hline Condição de ocupação da & \multicolumn{2}{|c|}{ Itaara } & \multicolumn{2}{c}{ Restinga Seca } \\
\cline { 2 - 5 } Residência Secundária & Número & Percentual (\%) & Número & Percentual (\%) \\
\hline Própria & 32 & 97 & 28 & 53 \\
Emprestada & 1 & 3 & 3 & 6 \\
Alugada & 0 & 0 & 22 & 41 \\
\hline TOTAL & 33 & 100 & 53 & 100 \\
\hline
\end{tabular}

Fonte: Dados da pesquisa (2008).

É possível visualizar na tabela 1 que o município de Itaara apresenta em quase sua totalidade (97\%) visitantes na condição de proprietários das residências, sendo inexistentes, no contexto da amostra, a presença de visitantes locatários. Já, por outro lado, em Restinga Seca, uma grande parcela dos visitantes caracteriza-se como locatário das residências, totalizando um percentual de $41 \%$, o que aponta um considerável contingente de proprietários que as utilizam com fins de geração de renda via locação imobiliária. Quanto à 
caracterização dos fluxos de finais de semana e de veraneio, em relação ao objetivo da viagem, a totalidade dos entrevistados informaram que a realizam exclusivamente com o fim de descanso e lazer. Em Itaara, todos já haviam visitado o local anteriormente; em Restinga Seca, 92\% dos visitantes apontaram o retorno ao local e às residências, sendo apenas $8 \%$ o total de visitantes que se encontravam pela primeira vez no local.

Apresenta-se, a partir dos dados contidos nas tabelas 2 e 3 , a denominação do município de Santa Maria como polo emissor, pois é o principal município de origem dos deslocamentos em direção às residências secundárias dos municípios de Itaara e de Restinga Seca.

Tabela 2. Município de origem da mobilidade espacial ao município de

Itaara

\begin{tabular}{lccc}
\hline \multicolumn{1}{c}{ Municípios } & Distância $(\mathrm{km})$ & Quantidade de casos & Taxa \% \\
\hline Polo Emissor - Santa Maria & 10 & 125 & 90 \\
Outros (8 municípios) $^{*}$ & 220 & 13 & 10 \\
\hline TOTAL & - & 138 & 100 \\
\hline
\end{tabular}

Fonte das ocorrências: Dados da pesquisa (2008).

Fonte das distâncias: DAER/RS (2008).

* Distância média dos demais municípios de origem dos fluxos de visitação.

Tabela 3. Município de origem da mobilidade espacial a Restinga Seca.

\begin{tabular}{cccc}
\hline Municípios & Distância $(\mathrm{km})$ & Quantidade de casos & Taxa \% \\
\hline Polo Emissor - Santa Maria & 65 & 77 & 43 \\
Outros (17 municípios) * & 76 & 92 & 57 \\
\hline TOTAL & - & 169 & 100 \\
\hline Fonte das ocorrências: Dados da pesquisa (2008). \\
Fonte das distâncias: DAER/RS (2008). \\
* Distância médias dos demais municípios de origem dos fluxos de visitação.
\end{tabular}

As taxas percentuais demonstram que o município de Santa Maria, com distância de 10 quilômetros de Itaara, é o município de origem de $90 \%$ dos visitantes, ao passo que Santa Maria representa $43 \%$ do percentual total de origem dos deslocamentos em direção a Restinga Seca, sendo a distância entre esses dois últimos municípios de aproximadamente 65 quilômetros. Observa-se que, em Itaara, são citados apenas 13 casos de municípios de origem diferentes de Santa Maria, constituindo apenas 10\% da amostra, sendo essa distribuída em oito municípios diferentes, com distância superior em todos os casos, perfazendo uma média de 220 quilômetros de Itaara. Já com relação 
a Restinga Seca, são 92 os casos de municípios de origem diferentes de Santa Maria, representando 17 municípios, que se refere a um percentual de $57 \%$ da amostra, de maneira que suas distâncias perfazem uma média de aproximadamente 76 quilômetros de Restinga Seca.

Outra característica marcante é o tempo de permanência nas residências secundárias, característica essa que apresenta relação com a distância entre o polo emissor (Santa Maria) e o espaço de residências secundárias. O gráfico 2 apresenta a distribuição dos visitantes de acordo com o tempo de permanência nas residências secundárias considerando as seguintes categorias: menos de 1 dia; 1 a 6 dias; de 1 a 2 semanas; mais de 2 semanas a 1 mês e; mais de 1 mês.

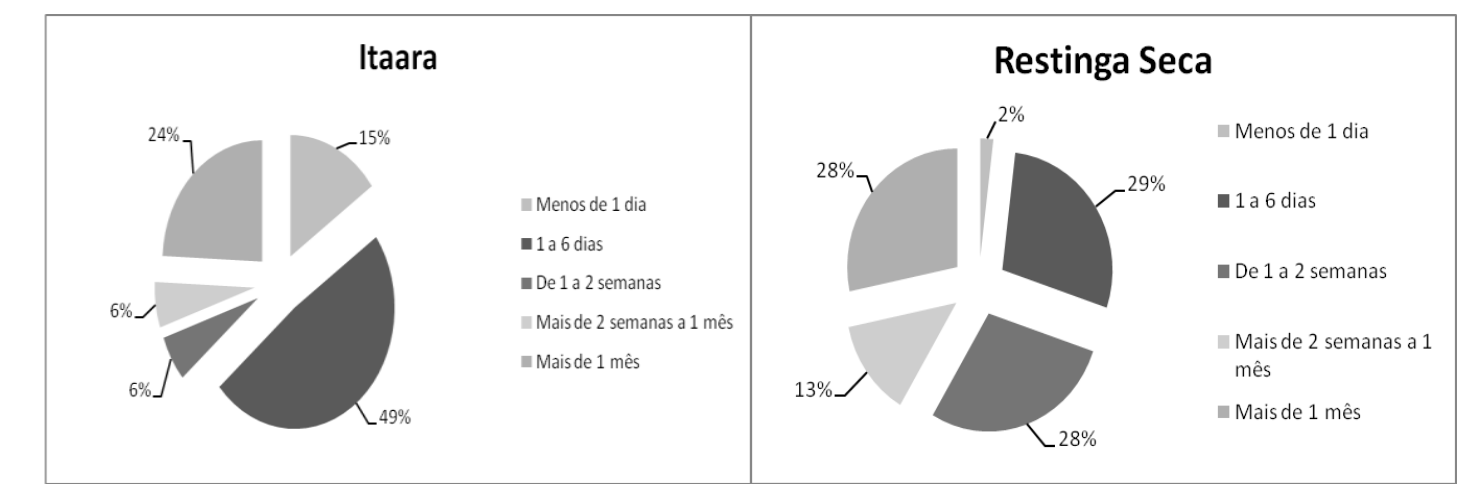

Gráfico 2. Tempo de permanência dos visitantes de Itaara e Restinga Seca nas residências secundárias

Fonte: Dados da pesquisa (2008).

Na observação comparativa do gráfico 2, destaca-se que em Itaara é expressivo o número de visitantes que permanece somente de um dia a seis dias no município, igualmente demonstrou taxas superiores a Restinga Seca. Após verificada a existência de um polo emissor em comum para os dois municípios em análise e destacado os períodos de permanência dos municípios, apresenta-se a seguir a caracterização dos fluxos de viagens.

Denominam-se fluxos de finais de semana àqueles que têm periodicidade, em geral, de finais de semana, mantendo um considerável número de ocorrências ao longo do ano (ainda que ampliadas no veraneio), bem como se denominam fluxos de veraneio àqueles que em suas periodicidades apresentam relevância apenas no período de veraneio, 
concentrando maiores ocorrências nos meses dezembro, janeiro e fevereiro, conforme se observa no gráfico 3.

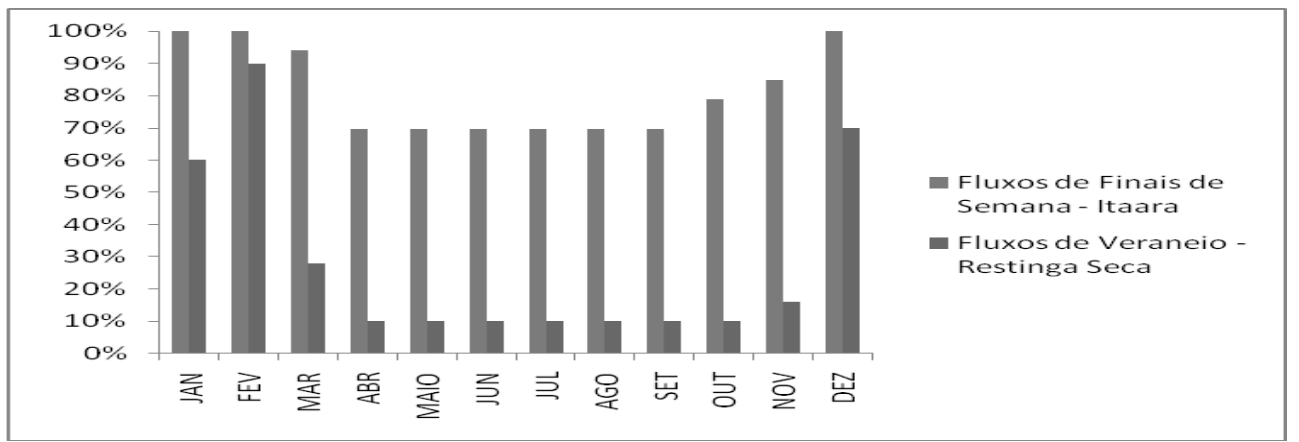

\section{Gráfico 3. Freqüência dos deslocamentos de residências secundárias ao ano}

Fonte: Dados da pesquisa (2008).

A partir dos dados expostos no gráfico 3, verifica-se que a totalidade dos visitantes de Itaara utiliza as residências secundárias com frequência ao longo do ano, ao passo que em Restinga Seca, costuma-se frequentar as residências secundárias de dezembro a fevereiro, fator, sobretudo, associado aos períodos de férias, característica bastante peculiar aos fluxos de veraneio.

A fim de contextualizar e no intuito de melhor compreender a variável distância e sua implicação nas periodicidades de usos das residências secundárias, observou-se na pesquisa que os fluxos de finais de semana apresentam distâncias de cerca de 15 quilômetros. Além disso, apresentam assiduidade maior nas visitas, as mesmas se deparam muito mais restritas ao polo emissor, ao passo que o fluxo de veraneio distancia-se cerca de 70 quilômetros, possuindo menor interação para com o polo emissor e constitui-se num fluxo mais disperso. Esta relação pode ser observada na figura 2. 


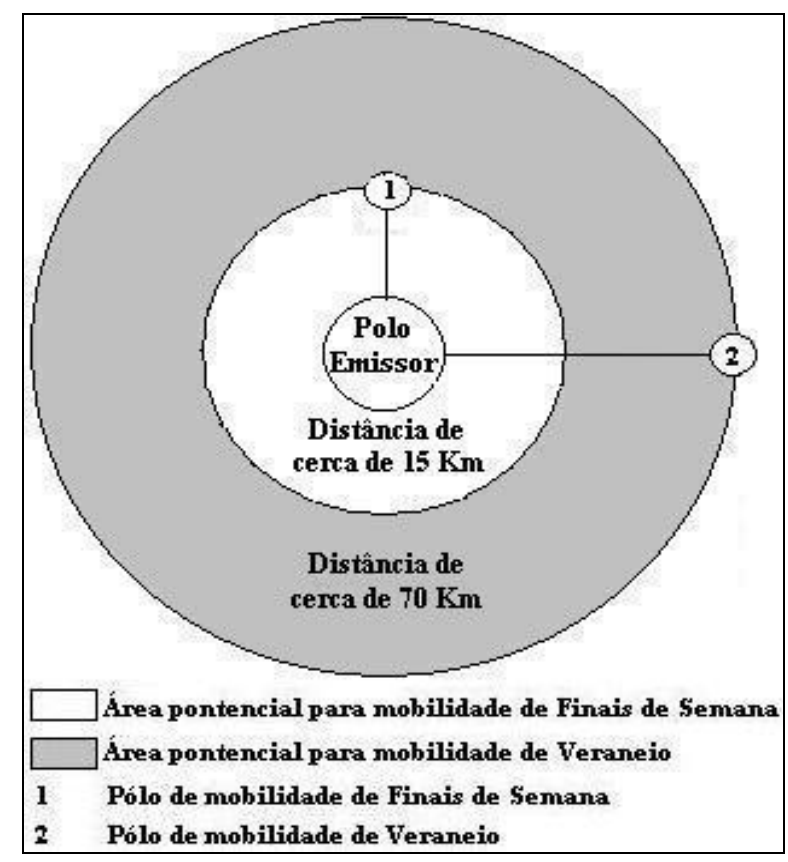

Figura 2. Esquema de relação entre distâncias e as Mobilidades no Espaço

Enfocando o modelo acima, porém, apresentado nos limites físicos dos municípios estudados, pode-se observar, na figura 3, a abrangência da relação entre distância e forma de manifestação da mobilidade espacial no contexto das diferentes distâncias dos municípios pesquisados em relação ao polo emissor.

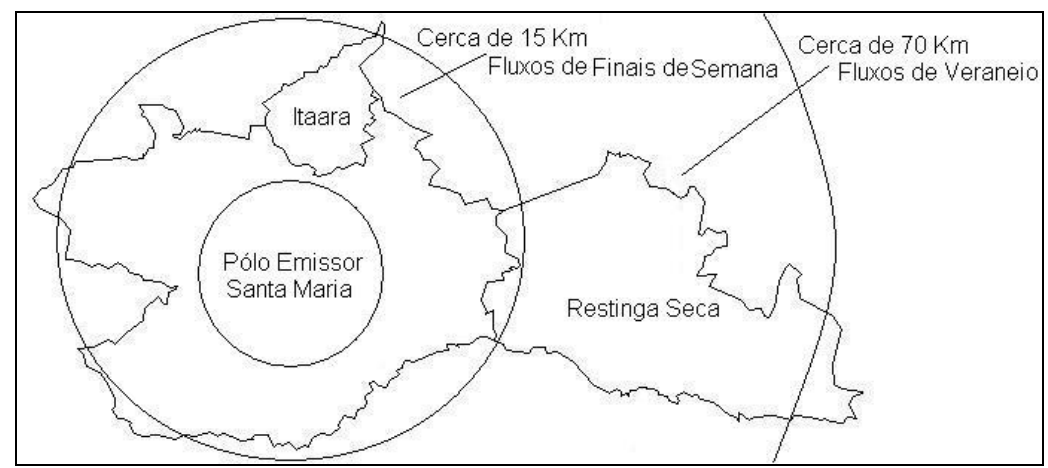

Figura 3. Esquema de relação entre distâncias e as Mobilidades Espaciais

Quanto ao perfil dos visitantes de residências secundárias entrevistados nos municípios pesquisados, contrariamente ao comumente esperado (majoritariamente por aposentados), o mesmo é constituído por percentuais semelhantes entre ativos e inativos. 
Tabela 4. Condição de ocupação segundo os municípios de Itaara e Restinga Seca

\begin{tabular}{c|c|c|c|c}
\hline \multirow{2}{*}{ Condição de ocupação } & \multicolumn{2}{|c|}{ Itaara } & \multicolumn{2}{c}{ Restinga Seca } \\
\cline { 2 - 5 } & Número & Percentual (\%) & Número & Percentual (\%) \\
\hline Não Declarado & 7 & 5 & 19 & 9 \\
Ativos & 64 & 46 & 101 & 47 \\
Inativos & 68 & 49 & 94 & 44 \\
\hline TOTAL & 139 & 100 & 214 & 100 \\
\hline
\end{tabular}

Fonte: Pesquisa de Campo (2008).

Conforme verificado na tabela 4, existe uma distribuição muito próxima entre as condições de ocupações. Essa situação parece ter relação direta com as formas pelas quais se dão os fluxos de deslocamentos, em geral efetuados em família. Em relação aos visitantes aposentados e pensionistas, Itaara apresentou 20 casos, o que representa pouco mais de $14 \%$, ao passo que em Restinga Seca houve 29 casos, pouco menos de $14 \%$ do seu total de visitantes, havendo, portanto, semelhança entre o público dessas residências secundárias. Salienta-se, ainda, que estes percentuais representam 1/3 dos inativos da amostra. Os estudantes por sua vez, representam cerca de 1/4 da amostra da pesquisa, apresentando, em Itaara, um percentual de 25\% (35 casos) e de $23 \%$ (49 casos) em Restinga Seca. A variável sexo não apresentou diferenças importantes, pois os percentuais tanto do sexo masculino quanto feminino oscilaram em torno de $50 \%$ da amostra da pesquisa. Quanto à característica renda (per capita), observou-se, nos municípios estudados, a distribuição apresentada no gráfico 4.

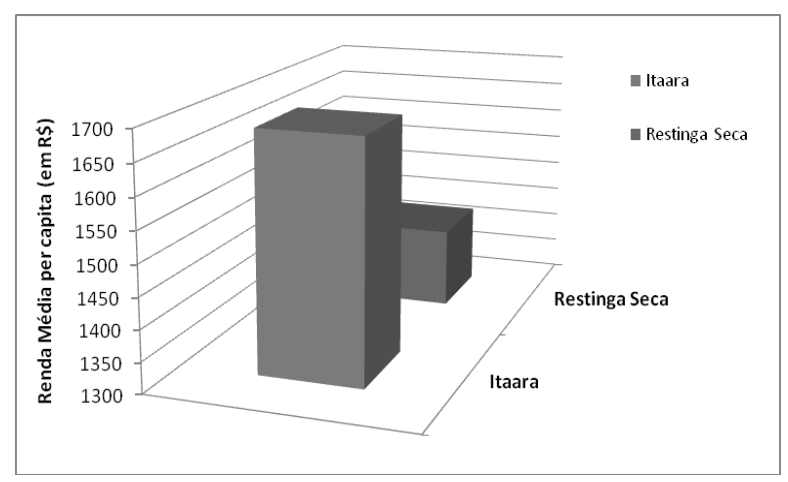

\section{Gráfico 4. Rendas Médias per capita dos Visitantes de Itaara e Restinga Seca}

Fonte: Dados da pesquisa (2008) ${ }^{10}$.

\footnotetext{
${ }^{10}$ Valores calculados com base no valor nominal do salário mínimo de 380 reais vigente até $02 / 2008$.
} 
No gráfico 4, verifica-se que a renda per capita média dos visitantes do município de Itaara é superior à de Restinga Seca. Tal relação assimétrica entre essas rendas tem origem no público que compõe as amostras, dado que 90\% dos visitantes do município de Itaara são compostos por moradores do polo emissor Santa Maria, que apresenta um setor terciário mais desenvolvido na região em função da sua vocação econômica voltada à prestação de serviços, sobretudo, com o estabelecimento dos serviços públicos estatais e federais, como a Universidade Federal de Santa Maria e as Bases Aérea e Militar e, além disso, apresenta um comércio bastante desenvolvido. Quanto ao município de Restinga Seca, dada a característica dos seus fluxos serem compostos por habitantes de municípios que têm como base econômica a agricultura (principalmente a agricultura familiar), tendo um setor industrial quase inexistente e um setor de serviços menos desenvolvido, características essas que se refletem diretamente nas dinâmicas urbanas dos mesmos e, logo, nos rendimentos do público das residências secundárias do município de Restinga Seca.

Os resultados dos rendimentos dos visitantes apresentados em ambos os municípios permitem identificar uma condição propícia a dispêndio econômico em gastos e investimentos no âmbito local, com possibilidade de influenciar positivamente a dinâmica da localidade de forma a contribuir com a dinamização desses espaços podendo, inclusive, transformar-se num dos vetores de desenvolvimento rural. As dinâmicas de consumo nos espaços de residências secundárias serão tratadas, na sequência deste artigo, com a apresentação dos dados referentes aos gastos realizados pelos visitantes nos locais desses imóveis e aqueles externos ao mesmo, podendo eventualmente proporcionar benefícios econômicos aos espaços em que se encontram instaladas as residências secundárias. Na tabela 5, são apresentados os resultados relativos às médias dos gastos efetuados pelos visitantes de residências secundárias nos municípios de Itaara e Restinga Seca. 
Tabela 5. Médias de gastos dos visitantes segundo os municípios de Itaara e Restinga Seca

\begin{tabular}{lccc}
\hline Município & Valor Mínimo por dia $(\mathrm{R} \$)$ & Valor Máximo por dia $(\mathrm{R} \$)$ & Média por dia $(\mathrm{R} \$)$ \\
\hline Itaara & 4,50 & 666,67 & 97,77 \\
Restinga Seca & 6,67 & 250,00 & 60,82 \\
\hline TOTAL MÉDIO & 5,59 & 458,34 & 79,30 \\
\hline
\end{tabular}

Através da tabela 5 é possível verificar que os gastos declarados pelos visitantes no município de Itaara são maiores que em Restinga Seca tanto em seu valor máximo quanto em sua média, enquanto seus valores mínimos são muito próximos e reduzidos em relação à média de ambos os municípios.

A autoavaliação do visitante quanto ao nível de gastos dividiu-se em três categorias: baixo, médio e elevado. A partir das respostas obtidas, obteve-se 0 gráfico 5 .

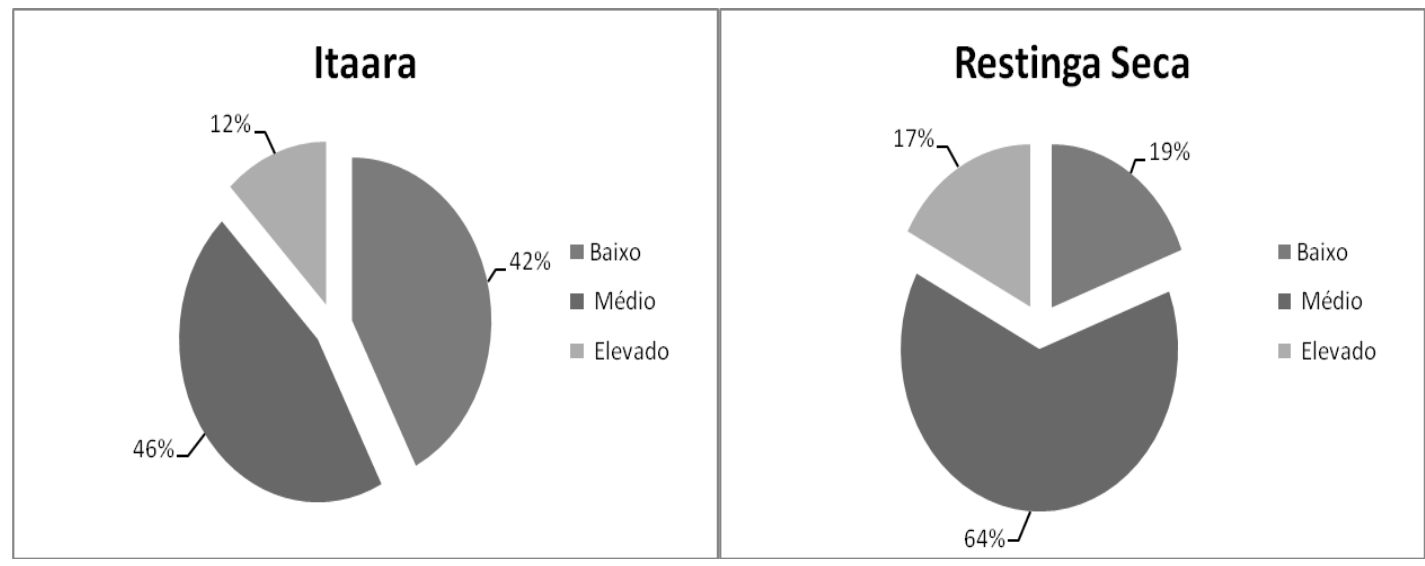

\section{Gráfico 5. Avaliação dos gastos pelos visitantes} Fonte: Dados da pesquisa (2008).

Verifica-se, no gráfico 5, que apenas a menor parcela informou que seus gastos sejam elevados, havendo em ambos os municípios a maior parcela afirmando que seus gastos se mantiveram na média de sua intenção. $A$ terceira e última parcela (42\% em Itaara e 19\% em Restinga Seca) aponta para um público importante, sobretudo, em Itaara, disposto a consumir mais desde que existam produtos à disposição, que atendam às suas demandas, preferências ou que despertem interesse de consumo. Porém, ressalta-se que 
apenas a menor parcela desses gastos ocorreu no âmbito local, conforme se visualiza no gráfico 6 .

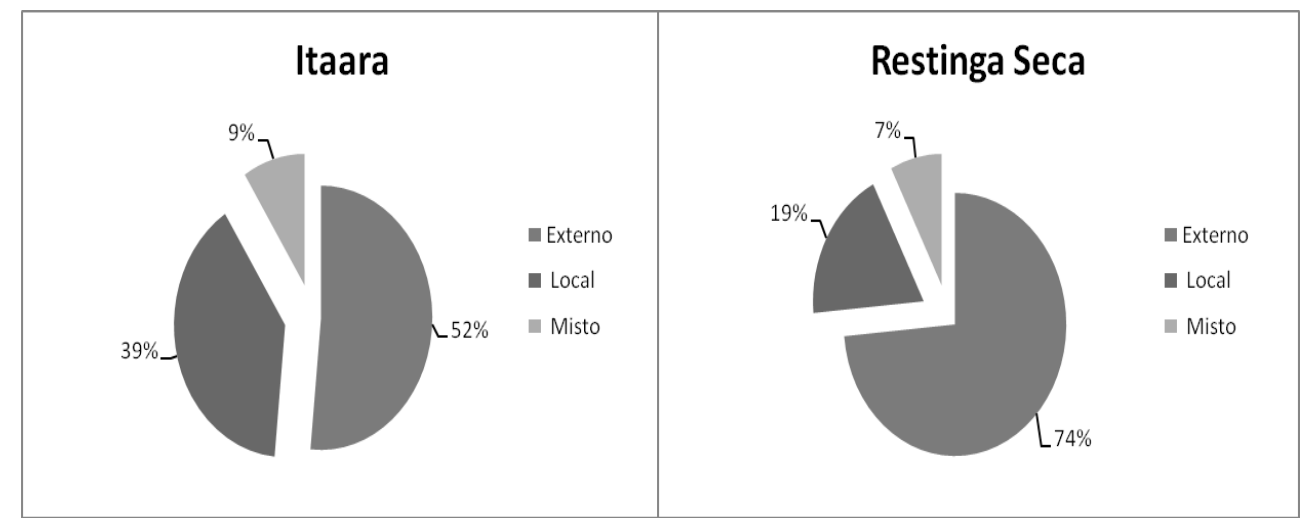

\section{Gráfico 6. Local dos gastos dos visitantes das residências secundárias} Fonte: Dados da pesquisa (2008).

Essa realidade apresentada se constitui numa realidade preocupante, sobretudo, em vista que reside no consumo uma série de aspectos favoráveis à atividade agrícola nos espaços rurais onde se localizam as residências secundárias. De acordo com Veiga (2003, p. 41 - 42):

[...] É o conjunto desses recursos patrimoniais que dá suporte a várias atividades econômicas. Só que é um equivoco pensar que a exploração econômica desse trunfo patrimonial esteja restrita às atividades turísticas. Ele também exerce forte influencia sobre os comportamentos residenciais de famílias de classe média, fator que pode viabilizar projetos de desenvolvimento local. Mesmo em países emergentes, como o Brasil [...] Como diz o economista Alain Rallet, da Universidade de Paris-Dauphine, a valorização do patrimônio é um meio de criar recursos específicos com o envolvimento dos atores locais.

Nesse caso, os atores locais podem ser envolvidos tanto pelos serviços quanto pelos produtos ofertados. Se, por um lado, as residências secundárias inegavelmente passam a ocupar espaços que anteriormente englobavam agricultura e/ou pecuária, por outro, apresentam-se como potenciais mercados consumidores, que passam supostamente a proporcionar uma série de benefícios. Esses benefícios podem se dar através da redução da cadeia de distribuição; seja pela simples aquisição do produto, encurtando o caminho dos mesmos até os mercados consumidores habituais, seja eliminando os "atravessadores" com a possibilidade da aquisição num espaço de tempo mais 
curto, reduzindo perdas ou, ainda, pelo potencial que a mesma representa em termos de diversificação da produção, uma vez que as demandas dos consumidores são variadas. Isso permite abrir um leque de possibilidades e alternativas aos agricultores das proximidades, bem como dos agricultores do entorno, chegando a envolver, inclusive, o artesão que pode disponibilizar suas peças nos espaços de comercialização.

Todos esses aspectos positivos são, na maioria das vezes, desconsiderados nas áreas de residências secundárias, não pela ausência de potencial para se desenvolverem, mas sim, pela falta de informação (tanto dos produtores quanto do poder público), falta de espaço adequado para comercialização ou, então, insuficiência de fomento capaz de viabilizar a comercialização ou mesmo organização para por em prática essas ações. $\mathrm{Na}$ esteira desse processo e como materialização do conjunto de elementos positivos que podem germinar em virtude das residências secundárias exemplo claro dos benefícios que daí podem advir -, encontram-se as organizações, associações e/ou cooperativas de agricultores que podem oferecer produtos em feiras itinerantes em dias e horários pré-estabelecidos ou em locais fixos.

A iniciativa de associação de produtores é visualizada no município de Itaara onde são característicos os fluxos de finais de semana. Essa iniciativa ainda é incipiente, mas conta com a disponibilidade de estrutura física proporcionada pelo poder público. Atualmente, diferentes produtores do município podem ofertar os seus produtos sem custo adicional e o lucro é revertido inteiramente ao produtor responsável pela produção. Além disso, a mesma envolve artesãos igualmente do município. Essa iniciativa foi denominada FEIRITA, que atua num sistema cooperativo entre os associados possibilitando oferta direta ao consumidor. A FEIRITA é gerenciada pelos próprios agricultores associados, adequando os horários de cada produtor àqueles em que se faz necessária a presença de algum deles na feira. Conforme um dos produtores-atendentes: 
continuam cuidando das terras e dos produtos que eles irão trazer prá cá ou vender adiante [...] mas sempre procuramos trazer tudo pra cá, pois além de ganharmos mais na venda, quando temos um freguês certo ele continua vindo até a feira e comprando sempre nossos produtos e alguma coisinha a mais dos outros [...] isso é bom pra nós e para os nossos colegas.

Somam-se, portanto, aos demais elementos acima, dois a mais na oferta de produtos agrícolas em áreas de residências secundárias, que são referentes aos próprios benefícios do sistema cooperativo: a "fidelidade" do consumidor e a aquisição de outros produtos juntamente àqueles habituais, beneficiando outro produtor que está ofertando produto diferenciado no mesmo local. Essa relação de "troca" gera benefícios mútuos a partir do momento em que outro consumidor que se dirigiu até a feira para comprar determinado produto adquire um produto diferente, além daquele que ele almejava comprar inicialmente. Essa relação de "retribuição" é capaz de gerar ampliação das vendas e, logo, acréscimo nos lucros individuais, assim como do coletivo, possibilitando a ampliação do mercado consumidor na ótica do produtor em particular.

A relevância das residências secundárias, conforme relato dos produtores/associados, confere às mesmas a incidência dos seguintes benefícios:

O pessoal de fora que tem casa aqui ou que aluga e vem para as casas aqui, não são os únicos compradores, mas com certeza sem eles nós não estaríamos vendendo na FEIRITA, eles são os principais compradores e também são os que têm mais dinheiro, podem gastar mais, levar mais coisas, então se não fossem eles nós ainda venderíamos todos nossos produtos aos mercados de Itaara ou de Santa Maria, não que não vendemos algumas coisas a eles ainda, mas agora vendemos apenas uma parte, a outra parte dos nossos produtos vendemos aqui mesmo na FEIRITA.

Essa exposição evidencia a melhoria trazida aos produtores associados à associação, todos eles agricultores familiares e com expectativas futuras a partir do início do empreendimento. Para além da venda dos produtos agrícolas, a geração de empregos diretos e indiretos foi verificada na exposição dos proprietários/agricultores: 
Geramos 2 empregos aqui na FEIRITA, mas nenhum deles é permanente, apenas quando temos muito movimento chamamos para nos ajudar, principalmente nos finais de semana quando temos mais movimento, aí sim, de resto somos apenas nós que cuidamos daqui [...] limpamos, organizamos e vendemos os produtos. (2 empregos indiretos gerados a moradores da localidade).

$\mathrm{Na}$ materialização desses benefícios socioeconômicos nos destinos dos fluxos de residências secundárias, faz-se necessária a observação quanto à distinção existente entre eles, ou seja, não se apresenta homogeneamente a oferta de produtos agrícolas aos deslocamentos de visitantes de finais de semana e de veraneio. Entretanto, na contramão de abordagens negativas referentes à possibilidade de tais iniciativas em espaços de fluxos de veraneio, aparecem perspectivas positivas e, que mesmo incipientes, já demonstram potencial, sendo capazes de articular mercados sazonais. Nesses mercados, existe uma potencialidade decorrente de um dado período de tempo, como o veraneio. Isso se dá, principalmente, por meio de produtos que possuem uma sazonalidade convergente com o período, como o abacaxi, a melancia e o morango, que carecem de rápido escoamento em vista da sua alta perecibilidade em períodos de altas temperaturas, tais como os meses de dezembro a março, no estado do Rio Grande do Sul, onde se observa que a venda destes produtos aos visitantes poderia beneficiar os produtores locais conforme demonstra a transcrição da entrevista apresentada na sequência desse artigo.

1) Gostaríamos de comprar produtos como frutas aqui, mas não vendem nada [...] 2) Só na semana passada vimos um senhor aqui e compramos [...] 1) Ah, é! Compramos alguns abacaxis dele e a um tempo tinha gente vendendo melancia aqui [...] compramos também. 3) Pois é! As outras vezes temos de ir de carro até a cidade comprar, é uma pena porque se vendessem aqui nós compraríamos mais vezes [...] 1) E verdade! Isso seria bom que fosse feito aqui, algum lugar que vendesse esses produtos [...] não só frutas mas verduras $\mathrm{e}$ outras coisas que além de quase não ter nada nos mercadinhos daqui, quase sempre estão feias pelo tempo que ficam paradas [...] (Diálogo de veranistas de duas residências secundárias em Restinga Seca/RS).

Com base nesses relatos, verifica-se a incidência de outros elementos que propiciam a comercialização dos produtos agrícolas nesses mercados 
consumidores, agora, porém, fazendo uso de alternativas, como mercado direcionado a produtos da estação, qualidade e preço, além da própria disposição de compra por parte dos indivíduos que se encontram nestes locais em seu período de lazer e descanso. Destaca-se, ainda, outro elemento que se refere à menor parcela de tempo que o vendedor teria de disponibilizar para efetuar a sua venda, podendo fixá-la em períodos menores e, em dias préestabelecidos, configurando mercados, tais como feiras que ocorrem uma, duas ou três vezes na semana. Desse modo, é possível contrapor a alternativa anterior de vinculação de oferta agrícola periódica, porém, oferecendo maior flexibilidade de tempo e demandas com maior homogeneidade de vendas no período de comercialização.

Esses elementos apresentados constituem-se em marcas dessa relação existente entre as residências secundárias, o espaço rural e as atividades agrícolas nele contidas, criando e ressignificando relações que extrapolam os aspectos físico e econômico, englobando cultura e a constituição da paisagem, ao mesmo tempo em que (re)valorizam e (re)vitalizam as áreas rurais, além de possibilitarem certa revalorização da própria atividade agrícola e de produtos rurais tradicionais. Assim, os resultados apontam que, mesmo não atingindo de forma homogênea e a todos os agricultores, esse canal de comercialização das atividades agrícolas já se apresenta como alternativa ao espaço rural de Itaara e sendo capaz de propiciar uma importante parcela dos rendimentos médios da economia local.

\section{CONCLUSÕES}

O espaço rural brasileiro há algum tempo, vem demonstrando novas perspectivas de forma a abranger não apenas as atividades agrícolas, como também, novas atividades não-agrícolas, como se observa nas opções e atividades geradas em torno das residências secundárias. As residências secundárias, abordadas no contexto do "novo rural", demonstraram especificidades nos deslocamentos espaciais dos visitantes, observando-se, também, relações e potencialidades derivadas das mesmas nos espaços em 
questão. Com relação aos municípios de Itaara e Restinga Seca, as especificidades nos deslocamentos concernem aos fluxos de finais de semana e de veraneio, respectivamente, caracterizados pelos períodos e intensidades de suas manifestações. No município de Itaara, observou-se que apresentamse maior distribuição ao longo do ano, dado ao fato de que a periodicidade de visitações se dá nos finais de semana, de janeiro a dezembro. No contexto destes fluxos de visitação, não ocorrem significativas oscilações nas demandas de consumo durante o ano. Em Restinga Seca, existe uma menor frequência nos fluxos de visitação ao longo do ano, porém com grande intensidade num curto período de tempo de maneira que, neste caso, configura-se um fluxo de veraneio.

As visitações com periodicidade de veraneio em Restinga Seca mostraram-se centradas em uma única área específica no município. Cabe ressaltar que tal fenômeno evidenciou-se num espaço mais distante do principal polo emissor, Santa Maria/RS, ao passo em que também demonstrou uma maior diversidade de municípios de origem dos deslocamentos em direção a Restinga Seca. Também, destaca-se o fato de que grande parte dos proprietários utiliza as residências secundárias como fonte de renda por meio da locação.

A periodicidade de finais de semana em Itaara foi marcada por sua manifestação ocorrer de forma mais dispersa no município e em espaços mais distantes entre as residências. Itaara, também, demonstrou uma menor diversidade de municípios que compõem a origem dos visitantes. Quanto a isso, cabendo destacar que esses municípios localizam-se mais distantes em relação aos deslocamentos de seus visitantes quando comparados aos realizados pelos visitantes de Restinga Seca desde seus municípios de origem. Além disso, as residências secundárias são utilizadas quase unicamente por seus proprietários, não existindo, nesse município, relações de locação. Esses proprietários utilizam o imóvel para fins particulares (geralmente com seus familiares) e apresentam maior renda per capita quando comparados aos visitantes locatários de Restinga Seca, bem como apresentam maior dispêndio financeiro (sobretudo em investimentos e contratações de serviços). Observou- 
se, ainda, o caráter urbano de origem desses fluxos, tanto de veraneio quanto de finais de semana, visto que quase a totalidade dos visitantes tem sua principal residência em espaços urbanos e buscam nas residências secundárias um ambiente para o descanso e lazer. Outro aspecto importante a destacar como resultado do presente estudo é a constatação de novas formas de ligação entre produtor e consumidor representada pela associação denominada FEIRITA, que parece representar uma alternativa consistente de comercialização onde os agricultores familiares podem se beneficiar, assim, assumindo o papel de protagonistas.

Com os resultados do presente estudo, verifica-se que o fenômeno de residência secundária manifesta-se não apenas em costas litorâneas no território nacional ou, então, como fenômeno exclusivamente europeu ou de países desenvolvidos, mas que as residências secundárias representam um fenômeno relevante em determinados espaços rurais em países como o Brasil, a exemplo dos municípios de Itaara e Restinga Seca, no Rio Grande do Sul, devendo-se considerar os seus impactos em qualquer análise do espaço, bem como em projetos que visem ao desenvolvimento do mesmo.

\section{REFERÊNCIAS}

ALMEIDA, J. A. A função estética e recreativa da agricultura. In: OLIVEIRA, C. G. de S. \& MOURA, J. C. de. O turismo rural como vetor do desenvolvimento sustentável. Anais... 4ํㅡㄹ Congresso Brasileiro de Turismo Rural. Piracicaba, 2003. p. 449 - 457.

ALMEIDA, J. A. Pesquisa em extensão rural. Um manual de metodologia. Brasília: Associação Brasileira de Educação Agrícola Superior, 1989.

ASSIS, L. F. de. Turismo de segunda residência: a expressão espacial do fenômeno e as possibilidades de análise geográfica. In: Revista Território. Ano VII, n. 11, 12 e 13. Setembro/Outubro, p. 107 - 122. Rio de Janeiro. 2003.

CERVO, A. L.; BERVIAN, P. A. Metodologia Científica. 5. ed. São Paulo: Pretice Hall, 2002.

COSTA, S. F. Estatística aplicada ao turismo. São Paulo: Aleph, 2003.

DAER - DEPARTAMENTO AUTÔNOMO DE ESTRADAS DE RODAGEM. Disponível em: <http://www.daer.rs.gov.br>. Acesso em 25 de nov. 2008.

DEL GROSSI, M. E.; GRAZIANO DA SILVA, J. O novo rural brasileiro: uma abordagem ilustrada. Londrina: Instituto Agronômico do Paraná, 2002. Vol. I. 
GRAZIANO DA SILVA, J. O Novo rural brasileiro. Campinas: Ed. da Unicamp, 1999. (Coleção Pesquisas, 1).

Unicamp, 1996.

A nova dinâmica da agricultura brasileira. Campinas: Ed. da

HALL, C. M., MÜLLER, D. Introduction: Second Homes, curse or blessing? Revisited. In: HALL, C. M., MÜLLER, D (Org.). Tourism, mobility and second homes. Between Elite Landscape and Common Ground. Toronto: Channel View Publications, 2004. p. 3 - 14. (Aspects of tourism, 15).

IBGE - INSTITUTO BRASILEIRO DE GEOGRAFIA E ESTATÍSTICA. Cidades. Disponível em: <http://www.ibge.gov.br>. Acesso em 12 de dez. 2007.

LOPES, A. S. Retomando a questão rural. In: PORTELA, J.; CALDAS, J. C. (Orgs.). Portugal chão. Oeiras: Celta. p. 281-299. 2003.

RICHARDSON, R. J. Pesquisa social: Métodos e Técnicas. 3 ed. São Paulo: Atlas, 1999.

RODRIGUES, I. da S. Desenvolvimento do turismo e conservação da paisagem: Estudo do Potencial Turístico de Itaara (RS). Santa Maria: Ed. Facos, 2005. (Série Dissertações em Turismo Rural, 07).

SAMPAIO, J. Considerações sobre a residência secundária em Esposende. Revista da Faculdade de Letras - Geografia. Porto, 1 série, v. 15/16, p. 131 143, 2000.

SANTOS, M. O espaço dividido. São Paulo: EDUSP, 2004.

SCHNEIDER, S. A Ocupação da força de trabalho na agricultura gaúcha: Uma análise a partir da pesquisa rural da EMATER/RS de 1992. Disponível em: $\quad$ <http://www.eco.unicamp.br/nea/rurbano/textos/downlo/emater.html>. Acesso em 22 set. 2007.

A pluriatividade na agricultura familiar. Porto Alegre: Ed. da UFRGS, 2003.

SCHNEIDER, S.; BLUME, R. A Ensaio para uma abordagem territorial da ruralidade: Em busca de uma metodologia. In: Revista paranaense de desenvolvimento. Curitiba, jul/dez, 2004. p. 109 - 135.

SENA, M. de F. A. de.; QUEIROZ, O. T. M. M. Impactos ambientais e sócioculturais do turismo de segunda residência: $O$ caso de Ponta da Tulha, Ilhéus, BA. Caderno Virtual de Turismo, vol. 6, n. 04, p. 94 - 106, ano 2006. Disponível em: $<$ http://www.ivt.coppe.ufrj.br/caderno/ojs/include/getdoc. php?id=488\&article=16 $2 \&$ mode $=$ pdf $>$. Acesso em: 26 dez. 2008.

TULIK, O. Turismo e meios de hospedagem: Casas de temporada. São Paulo: Roca, 2001.

VEIGA, J. E. Cidades imaginárias: o Brasil é menos urbano do que se calcula. Campinas: Autores Associados, 2003. 